\title{
Study of Old City Plan With Help of Historical Ontology of Urban Spaces - Legend Reconstruction
}

\author{
Katarzyna Słomska-Przech \\ Tadeusz.Manteuffel Institute of History, Polish Academy of Sciences - kslomska@ihpan.edu.pl
}

Keywords: old plans, ontology, urban history, plan legend, reconstruction

\section{Abstract:}

Project Historical Ontology of Urban Spaces (HOUSe) aims at developing domain ontology (also referred to as urbanonto), which represents concepts related to historical cities. In recent years ontologies have been successfully implemented in historical research (Southall and Aucott 2019; Szady 2020). The HOUSe ontology models definitions of terms, responding to the needs of the research community for comparable specialist terminology, which is essential for comparative urban studies by conditioning mutual understanding of researchers (Denecke 2017). The upper level ontology for the urbanonto ontology is CIDOM-CRM. The urbanonto is based on the modern model of a database - that is the Database of Topographic Objects used officially in Poland. It benefits also from the ontohgis ontology, a domain ontology collecting information on historical administrative units (Szady 2020). Researchers participating in the project supplemented the list of terms from the modern database with types of objects existing in the cities in the past. One of the advantages of our approach is that for the territory of Poland it will allow for comparative research of historical space and contemporary space for which data repositories exist. Application of ontology in relational databases is profitable for effective data retrieval and sharing of information and knowledge (Fonseca et al. 2000; Munir and Sheraz Anjum 2018). The HOUSe ontology was used to develop the database model for collecting data about objects in the city.

The main case study in the HOUSe project is the city of Warsaw. The essential cartographic source for this area is the city plan on the scale of 1:2,500 (Figure 1). It was elaborated in the second half of the 19th century under the direction of William Heerlein Lindley in connection with the construction of water supply and sewage systems (Żelichowski and Weszpiński 2016). W.H. Lindley was a British engineer who supervised similar works, e.g. in Czechia or Romania. At that time in Warsaw, a whole series of plans in various scales were created. These were the first fully cartometric plans based on geodetic control network points. However, no legends were attached to the plans on scale of 1:2,500. A small number of examples of symbols (named as 'conventional signs') used on the maps appeared only on two different sheets in the $1: 1,000$ scale.



Figure 1. Fragment of Lindley's plan at a scale of 1:2,500 (State Archive in Warsaw, 72/1001 sig. 785, sheet no 11)

As of today, the HOUSe ontology consists of 286 object types and is constantly developed with the progress of the project. The above-mentioned two sets of symbols used on Lindley's plans contain far fewer object types. One of the sheets presents only 11 symbols, and the second one 15 (Table 1). These two sets of cartographic symbols constituted the basis for the reconstruction of the legend of the plan on the scale of 1:2,500 used in the project. Four symbols appear in both sets (farmlands, waters, roads, ditches\&canals), resulting in 24 unique symbols. At the current stage of the urbanonto 
development set of symbols from Lindley's plans could be mapped to 14 types of objects from HOUSe ontology (Table 1). However, much more symbols appear throughout the sheets of the plan on a scale of 1:2,500. What is more, a noticeable distinction with regard to the symbols of buildings could be made. Another important problem in relation to the analysis of urban tissue is the ambiguity of the line symbols of the borders between plots.

\begin{tabular}{|c|c|}
\hline symbols from Lidleys' plans & object types from HOUSe ontology \\
\hline buildings & building \\
\hline estates & property \\
\hline gardens & garden \\
\hline cultivated gardens & \multirow{2}{*}{ cultivation on arable land } \\
\hline farmlands & \\
\hline meadows & \multirow{6}{*}{ grass } \\
\hline overgrown meadows & \\
\hline dry meadows & \\
\hline wet meadows & \\
\hline pastures & \\
\hline overgrown pastures & \\
\hline thickets, shrubs & shrub \\
\hline alder forest & \multirow{3}{*}{ forest } \\
\hline oakwood & \\
\hline pine forest & \\
\hline swamps\&wetlands & swamps \\
\hline sands & sandy or gravel ground \\
\hline roads & \multirow{2}{*}{ road } \\
\hline chaussee & \\
\hline alleys & alley \\
\hline waters & surface water \\
\hline ditches\&canals & drainage ditch/canal \\
\hline wastelands & \multirow{2}{*}{ the remaining unused land } \\
\hline fallows & \\
\hline
\end{tabular}

Table 1. Attempt of mapping symbols from Lindley's plans to object types from the urbanonto (own elaboration).

In conclusion, it is worth harmonizing the data from different time periods in order to conduct systematic studies of urban space through history. The work on a larger scale can positively contribute to comparative studies of cities. The key issue is the consistency of understanding of concepts by researchers from different countries, and this consistency can be achieved through ontology. Systematic work on the extension of the ontology with objects from the past shows which objects are no longer present in the city space, and enables the study of the continuity of objects as well as the continuity of space.

\section{Acknowledgements}

This research was funded by the National Agency for Academic Exchange, Poland, project

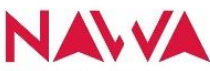
number PPI/APM/2019/1/00053/U/00001, "Historical Ontology of Urban Space".

\section{References}

Denecke, D., 2017. 'Comparative Approaches in the Historico-topographical Analysis of Towns and Cities' In: Lords and towns in medieval Europe. The European historic towns atlas project, eds HB Clarke \& A Simms, Taylor and Francis, London, pp. 33-61.

Fonseca, F., Egenhofer, M., Davis, C. and Borges, K., 2000. 'Ontologies and knowledge sharing in urban GIS', Computers, Environment and Urban Systems, vol. 24, no. 3, pp. 251-272.

Munir, K. and Sheraz Anjum, M., 2018. 'The use of ontologies for effective knowledge modelling and information retrieval', Applied Computing and Informatics, vol. 14, no. 2, pp. 116-126.

Southall, H. and Aucott, P., 2019. 'Expressing History through a Geo-Spatial Ontology', ISPRS International Journal of Geo-Information, vol. 8, no. 8, p. 362.

Szady, B. (ed.) 2020. Metodologia tworzenia czasowo-przestrzennych baz danych dla rozwoju osadnictwa oraz podziałów terytorialnych. [Methodology for building spatio-temporal databases of settlement development and territorial divisions] Available from: https://zenodo.org/record/3751266\#.YJwbpqgzZZU [12 May 2021].

Żelichowski R., Weszpiński P.E., 2016. William Heerlein Lindley. Plan Warszawy 1912. Plan niwelacyjny miasta Warszawy. Zdjęcie pod kierunkiem Głównego Inżyniera W.H. Lindleya, Warszawa. 